\title{
Tip Work: Examining the Relational Dynamics of Tipping beyond the Service Counter
}

\author{
Eli R. Wilson (1) \\ University of New Mexico
}

\begin{abstract}
Tips constitute a growing form of income for roughly three million American workers today. While existing scholarship on tipping focuses on worker-customer dynamics, it neglects the implications of gratuities beyond the service counter. Drawing on the case of restaurant workers in Los Angeles, this study analyzes tip work, the bundle of social relations and labor experiences framed by tips in commercial settings. I argue that tipping strains relations between subgroups of workers who, despite collectively producing service, are subject to unequal access to tip earnings. Tips thereby shape relations among workers in ways that exacerbate existing organizational and social hierarchies.

Keywords: tipping, service work, restaurants, inequality, ethnography, labor relations
\end{abstract}

\section{INTRODUCTION}

In the United States, tipping has become an increasingly common aspect of public life. Three million Americans today work for tips, while tipping customers leave an estimated $\$ 47$ billion dollars in gratuities in U.S. restaurants alone (Azar 2011). Despite the ubiquity and economic significance of tips in a service-based economy, sociological scholarship on the topic remains narrowly concentrated in two areas: micro-interactions between customers and workers (Azar 2007; Brewster and Wills 2013; Davis 1959; Mars and Nicod 1984; Thompson 2015) and the precarity associated with many tipped service jobs (Ehrenreich 2001; Paules 1991). Taken together, this body of research suggests that tipped service workers must frequently contend with marginalized labor conditions characterized by dependence on unreliable and discriminatory tipping practices of customers (Azar 2007; Lynn and McCall 2000; but see Sallaz 2009).

Focusing solely on tipped employees and their interactions with customers ignores a broader set of workers, relations, and practices within many tipped service

Direct all correspondence to Eli R. Wilson, University of New Mexico, Department of Sociology \& Criminology, MSC05 3080, 1915, Roma NE, Ste. 1103, Albuquerque, NM 87131-0001; e-mail: erwilson18@gmail.com.

Symbolic Interaction, (2019), p. n/a, ISSN: 0195-6086 print/1533-8665 online. (C) 2019 Society for the Study of Symbolic Interaction. All rights reserved.

DOI: 10.1002/SYMB.413 
workplaces. Beyond the service counter, different types of employees and supervisors maintain structurally unequal relationships with both tipping customers and the gratuities they leave behind. Whether in hotels, restaurants, spas, or casinos, workers operate in distinct capacities and time sequences along an arc of service work (Sherman 2007; Strauss 1985; Subramanian and Suquet 2017). Front-of-the-house workers interact primarily with customers, while back-of-the-house workers produce and maintain service goods (Sherman 2007). Support workers, meanwhile, function in hybrid roles, such as by laboring in the presence of guests while doing tasks that are virtually invisible (e.g., bussing tables). These internal distinctions can have very real consequences for workers. Different categories of service labor not only require distinct types of tasks and skills but also result in asymmetrical work schedules, shop floor interactions, and total earnings (Adler and Adler 2004; Wilson 2017). In U.S. metropolitan restaurants, for example, servers and bartenders typically work shorter hours than cooks, but with tips, these dining room-based employees can earn two to three times more per hour than kitchen-based employees (Haley-Lock and Ewert 2011).

Many restaurants and other kinds of interactive service establishments also maintain a social division of labor along race, ethnic, class, and gender lines. Those situated in front-of-the-house jobs are often disproportionately white, class-privileged men and women, while those in the back of the house are disproportionately immigrant Latino men (Gomberg-Muñoz 2011; ROCU 2014; Waldinger and Lichter 2003; Wilson 2017). Studying the "downstream" implications of tips - that is, what transpires away from customers and after a gratuity is handed over - matters precisely because of how it can imprint the social and organizational relations found within interactive service settings.

How does tipping impact the labor dynamic between different types of workers within tipped workplaces who may already be separated by social inequalities? Moving the study of tipping beyond the service counter, I seek to analyze tip work, the social relations and labor experiences in a given workplace that are shaped by tips. To provide an illustrative case of tip work, this study examines restaurant work in Los Angeles. Full-service restaurants in "global" U.S. centers remain iconic and enduring settings to study the implications of tips. Over half of all tipped workers today are located in the food-service industry (Conlin, Lynn, and O'Donoghue 2003), while restaurants and bars themselves play an outsized role in the revitalized urban economies of large postindustrial centers (Lloyd 2010; Ocejo 2014). This research examines how the unequal distribution of gratuities among restaurant workers in three LA-based restaurants exacerbates social and structural inequalities between them while also fostering tenuous workplace alliances. I show how tip work involves interpersonal displays, attitudes, and negotiations that can be interpreted in different ways by fellow workers. I close by elaborating a general framework for how tipping affects a broader web of social relations within contemporary interactive service settings, thereby extending a critical sociology of work to tipped labor. 


\section{TIPPED EMPLOYMENT IN THE UNITED STATES}

The institution of tipping goes back at least to the nineteenth century in the United States and Britain, with roots arguably tracing back to medieval times (Azar 2004). Some scholars locate the origins of tipping in the European caste-class system, where small monetary gifts from the wealthy to the servant class were commonplace (Segrave 1998). The custom of tipping was then imported to the United States by European travelers sometime in the late nineteenth century (Schein and Wohlfahrt 1984). Despite early opposition to the practice, tipping became the norm in many low-end American service settings such as restaurants, hotels, and railroad cars (Santino 1989; Segrave 1998). As a result, leaving a gratuity has long been associated with a hierarchical exchange between socially-privileged service consumers and socially-subordinate service producers.

Much of the social science research on tipping focuses on customer-worker interactions. Tipping is seen as a particular kind of economic exchange influenced by economic factors as well as sociocultural ones (Azar 2007; Bearman 2009); a customer's tip is only loosely related to the perceived quality of service they receive (Kim, Nemeschansky, and Brandt 2017; Lynn and McCall 2000). Tipping has been shown to vary based on the social characteristics of both customers and servers (Azar 2007; Brewster and Mallinson 2009). Men tip more than women on average, but also tip more to female servers than male servers (Lynn and Latane 1984). Whites tend to get bigger tips from customers than nonwhites (Brewster and Wills 2013). Similarly, various aspects of the service encounter itself can affect tipping: lightly touching guests on the shoulder, for instance, can lead to bigger tips, as does repeat patronage to an establishment (Azar 2007; Crusco and Wetzel 1984; Lynn 2006; Lynn and McCall 2000).

The volatility of tipping renders working for tips highly unreliable. Tipped workers remain vulnerable to factors beyond their control, including customer sexual advances (Cobble 1991; Ehrenreich 2001; Spradley and Mann 1975), contingent work schedules (Lambert, Haley-Lock, and Henly 2012), and low hourly base wages (Jayaraman 2018). In all but eight states, employers are legally allowed to pay tipped workers as little as $\$ 2.13$ an hour, with the assumption that a "tip credit" will allow these workers to match or surpass the regular minimum wage (currently $\$ 7.25$ at the federal level). At the same time, reports continue to surface regarding employer violations of tip laws, such as illegally siphoning employee tips or failing to pay out wages to meet the minimum wage should tips be insufficient (Foshay 2016). Facing unreliable employment protections, the economic livelihood of many tipped workers remains contingent on the goodwill of customers and the labor conditions set forth by employers.

To combat this unpredictability, tipped workers develop strategies for interacting with customers. For instance, they may upsell guests on more expensive menu items (Paules 1991) or engage in flirtatious or sexually suggestive behaviors aimed at eliciting a bigger tip (Erickson 2009; Ronai and Ellis 1989). Workers reward customers 
they perceive to be good tippers with extra care, insider access, and service personalization, while sanctioning poor tippers with inferior service or by rejecting humiliatingly low tips outright (Erickson 2009; Mars and Nicod 1984; Paules 1991; Sallaz 2009). By striving to actively make tips from their interactions with customers rather than passively receive them, tipped workers gain a sense of control and empowerment over their service jobs (Brewster and Wills 2013; Gatta 2002; Mars and Nicod 1984; Mulinari 2016; Paules 1991; Sallaz 2009; Thompson 2015).

Tipped workers also approach their interactions with coworkers and supervisors in strategic ways. Fellow tipped workers may collaborate on labor tasks with the mutual goal of bringing more gratuities into the establishment (Lewis 2006). They may also attempt to stabilize their tip earnings by pooling together and sharing their gratuities among a larger group of coworkers instead of handling them on an individual basis (Mulinari 2016). The fact remains that gratuities can be significant sums of money, especially to low-wage workers, and how these sums are divvied up rarely results in all workers receiving what they perceive to be their fair share. Tips, or more accurately the redistribution of tips, are likely to impact horizontal (intra-worker) and vertical (worker-manager) labor relations in specific ways. For example, lesser-tipped or untipped workers may end up participating in their tipped colleagues' attempts to garner more gratuities from guests, but they may also resist these efforts, or be excluded from these "entrepreneurial games" entirely (Sallaz 2009). Similarly, workers may seek support from managers in helping secure favorable conditions to make tips.

Surveying the broader web of relations found in many tipped labor settings, it is clear that the largest proportion of gratuities does not necessarily go to those with the most authority. The distribution of tip money need not follow organizational hierarchies. Frontline managers and supervisors, for instance, are often barred from receiving tips by federal law. ${ }^{1}$ Other types of employees may access only a small portion of gratuities, referred to as a "tip-out." Because tips are usually less regulated than employer-derived wages, behind the scenes, the practice of tip-outs often involves power dynamics between workers of different rank (Subramanian and Suquet 2017). Some workers maintain greater authority to redistribute tips as they see fit. As I will show, different types of service workers are not only subject to unequal access to tip money, they are also drawn into tense relations and tenuous alliances as a result of tips.

\section{THE STRUCTURE OF RESTAURANT WORK}

As in other tipped service workplaces, full-service restaurants commonly feature a cast of workers who operate in distinct and unequal capacities (Lopez 2010). While each of these positions may be integral for coordinating the hidden work of smooth client service (see Corman 2017), they often come with unequal access to tips. In restaurants, workers are commonly categorized as tipped, tipped-out, or untipped, which roughly mirrors a worker's proximity to customers in a service 
capacity. Workers who directly interact with guests, such as servers and bartenders, typically garner the majority of gratuities left by diners. Those with indirect contact with diners, such as bussers and food runners, receive a smaller tip-out ranging from a few dollars to roughly half the gratuities that servers will take home. ${ }^{2}$ Employees who labor behind the scenes or away from customer contact rarely receive any tips at all. This category includes, most prominently, back-of-the-house workers such as cooks and dishwashers, but also encompasses tip-exempt floor supervisors and chefs who are responsible for overseeing the dining room and kitchen, respectively.

The resulting earning imbalance between different types of workers in the same restaurant due to tips can be substantial. Workers of roughly equivalent rank laboring just feet from one another end up divided into economic winners and losers on a nightly basis. Cooks and other back-of-the-house workers remain among the lowest hourly wage earners in the country, often making less than $\$ 13$ an hour (roughly $\$ 25,000$ annually) - hardly a livable wage in most U.S. metropolitan centers (ROCU 2014; US Bureau of Labor Statistics 2017). By contrast, front-of-the-house workers in urban restaurants can top $\$ 30$ an hour in combined tips and wages, sometimes earning as much as six figures annually (Haley-Lock and Ewert 2011). ${ }^{3}$

Away from customers, differential access to gratuities can place tipped front of the house workers and untipped back of the house workers in tension with one another. ${ }^{4}$ Earning inequalities between fellow workers complicate traditional organizational and status hierarchies at the restaurant, where income may not accurately reflect the skills and training required for the job (see Fine 2009). A restaurant manager quoted in Azar (2011) laments that tipped customer service jobs requiring only two months of training are compensated at twice the rate of a job that requires two to five years of experience. This disparity impacts not only the interactional dynamic within the workplace (as I detail later), but the industry composition as a whole. As several recent reports note, the strong financial incentives for workers to seek tipped service jobs has contributed to a shortage of quality cooks in cities traditionally known for their vibrant restaurant scenes, like San Francisco and New York (Ferro 2015).

Tip disparities between types of restaurant workers also exacerbate existing social divides in restaurant workplaces along the lines of race, class, and gender. In Los Angeles and other large U.S. metropolitan areas, back-of-the-house, untipped restaurant jobs are racialized as "brown-collar" work mostly held by unskilled Latino immigrant men (Cantazarite 2000; Gomberg-Muñoz 2011; Waldinger and Lichter 2003). By contrast, front-of-the-house, tipped jobs are disproportionately held by class-privileged, white, young men and women, who managers believe to represent the "right" social and physical assemblage that will help attract customers (Jayaraman 2014; ROCU 2014; Williams and Connell 2010; Wilson 2016). These two categories of racialized, classed, and gendered jobs make up durably unequal worlds of work within restaurants (Wilson 2017).

The unequal distribution of tips thus layers onto an already socially segmented service workplace. While existing scholarship on tipping focuses primarily on customer-worker interactions, by examining the downstream consequences tipping 
has in Los Angeles restaurants, this article reveals the complex labor relationships impacted by tips and the uneven socioeconomic playing field tipping engenders.

\section{METHODS AND FIELD SITES}

The data in this study draws from over six years of ethnographic research conducted between 2012 and 2018 in upscale, full-service restaurants in Los Angeles. Participant observation is uniquely suited for capturing the everyday micro-interactions between different types of workers that are typically obscured from public view (Katz 1997). During my fieldwork, I gained employment as a restaurant server in three Los Angeles-based restaurants, ${ }^{5}$ working between two and five shifts a week, and totaling over 500 hours at each location. During this time, I kept a daily record of the shift worked (lunch or dinner), tips received, and the "section" of tables I was assigned. Following Emerson, Fretz, and Shaw (2011), the ensuing analysis stems from meticulously-kept field notes, written up immediately after leaving my shift, documenting my observations, interactions, and informal conversations with fellow workers, supervisors, and customers. To supplement this data, I conducted fifty-six in-depth interviews, forty-eight with workers, seven with managers, and one with the director of a restaurant industry non-profit organization. These interviews lasted thirty to ninety minutes each; I recorded most (with interviewees' permission) on a handheld electronic device and transcribed them immediately afterward.

The three restaurant field sites in this study - referred to here by the pseudonyms Match, Terroir, and The Neighborhood - were selected non-randomly and as part of a larger research project on labor and inequality within upscale restaurants in Los Angeles. Each of the field sites is higher end (listed on Yelp as 11-60 dollars per person), with medium-sized operations (30-80 total staff), and located in affluent neighborhoods. Each restaurant includes the common social segmentation of labor based on race, class, and gender: the overwhelming majority of back-of-the-house and support workers are first- and second-generation, working-class Latino men, while front-of-the-house workers are college-educated, white men and women. The latter group also tend to be more uniformly young and with limited family obligations: the average server, bartender, or host in this study is unmarried, childless, and in their late-twenties.

Match, Terroir, and The Neighborhood differ in their tip policies and the total amount of gratuities typically earned per shift by a given tipped worker. New hires at each restaurant learn about tip policies formally, during orientation, and tip norms informally, from talking with other workers (in my experience, supervisors rarely intervene with established tip procedures because this money legally belongs to workers, not restaurant management). At Match, servers and bartenders individually distribute a portion of their tips to bussers, food runners, baristas, and hosts, keeping the rest for themselves. The formula for tipping out is based on net sales, with payouts for each server totaling approximately $5 \%$ of their sales. For example, 
a server who sells $\$ 1000$ worth of food and drink and receives $\$ 200$ in tips would tip out a total of $\$ 50$ to various support staff workers and take home $\$ 150$ in tips. Over the duration of my time at Match, working a combination of breakfast, lunch, and brunch shifts, my average tips per server shift were $\$ 153$, which averaged out to over $\$ 30$ an hour in tips and wages combined. By contrast, cooks made an hourly rate of roughly $\$ 13$ (at the time of study), a rate that was consistent across all three restaurants.

At Terroir and The Neighborhood, tips are pooled in similar ways. At the end of every shift, servers and bartenders place their tips in a collective pot. Total tips are then tallied and distributed among all dining room employees based on a point system for each position: six points for servers, three points for bussers and food runners, and one point for hosts. Based on this formula, if servers "walk" with $\$ 160$ in tips, bussers and food runners will take home $\$ 80$, and hosts $\$ 27$. If a worker leaves a shift early or is asked to stay late, their point total can be adjusted up or down accordingly. This policy, however, is subject to negotiation, and remains at the discretion of whomever is counting and distributing tip money at the end of the shift. Despite having similar tip pool systems in place, average tip earnings differ substantially at Terroir and The Neighborhood. This is due to both higher customer traffic at The Neighborhood coupled with Terroir's managerial decision to staff a higher ratio of front-of-the-house workers to customers. This spread the tip pool thinner at Terroir. My personal tip records from Terroir indicate that servers averaged $\$ 96$ in tips across lunch and dinner shifts - slightly more during the latter-whereas at The Neighborhood, servers averaged $\$ 196$ in tips, the most of all three restaurants.

\section{"WHERE'S MY TIP, HUH?": EXACERBATING SOCIAL TENSIONS BETWEEN WORKERS}

At Match, Terroir, and The Neighborhood, tips flow primarily to servers and bartenders, trickle down to bussers and food runners, and are withheld from the kitchen staff. This unequal distribution of tips can easily fray personal relations between coworkers or prevent them from developing rapport in the first place.

Rodrigo, a Salvadoran cook in his twenties, feels it is unfair for his coworkers who "carry plates and take orders all day" to earn substantially more money than he and his kitchen comrades. Rodrigo says he tries to compartmentalize this fact in the back of his mind in order to concentrate on grilling steaks on the plancha (griddle). But the subject of tips can flare up at a moment's notice, exposing an otherwise quiet class conflict between workers. Rodrigo still has not forgiven Freddy, a Latino food runner a few years older than he, for jokingly waiving a wad of tips in his face and telling him, "Thank you for making me all this!" Says Rodrigo, "I just wanted to punch him in the face that day. I told him, 'You are a bold man for saying that. Say it again and we are going to have a problem"” (Interview, August 4, 2016). 
Tensions between tipped and untipped workers at the restaurant also manifest in the form of thinly veiled jabs and oblique comments. As Rodrigo's (mostly) silent fuming about Freddy's behavior indicates, tips frame how workers understand their coworkers' actions. Consider the following field note from Terroir at the end of a Saturday night shift:

Eric [cook, Latino, male] and Tony [cook, white, male] are cleaning the grill in the kitchen as I walk up to them. All of us have been working nonstop for the last five hours, me taking care of guests in the dining room, and them taking care of a seemingly never-ending line of food tickets. Eric and Tony look tired.

Tony pauses upon glancing at me, his eyes squinting: "Oh, so looks like you guys are singing a different tune now that you've made a lot of money tonight." His voice is thick with sarcasm.

"Huh?" I say, feigning shock. "What do you mean?"

"Before the shift, you people were complaining about being tired or whatever, but now everyone is bouncing around, happier because you've made your tips!" $\mathrm{He}$ shakes his head. Eric nods and smiles sheepishly. He looks down and continues cleaning. "Well, where's my tip, huh? Huh?!" Tony adds, smirking and holding out an open palm. (Field notes, Terroir, November 14, 2015)

Tony and I had engaged in friendly interactions in the past, including slapstick banter and excited conversation about new restaurant openings in the city. But that night, Tony was much less friendly. Our status as social peers had been strained by tip-fueled economic disparity. The $\$ 15$ per hour he had made over the last 8 hours - Tony was among the highest paid line cooks - was no match for the \$180 that I, like the rest of the servers, was taking home in tips alone. Tony's sarcastic comment about tips ("Well, where's my tip, huh?") speaks directly to the hot-button issue that complicates his relationship with his dining room coworkers.

For other workers, access to a small portion of tips rarely lessens frustration with the way tips are distributed. Food runners, hosts, and bussers at each restaurant are chronically dissatisfied with the tip-outs they receive from servers and bartenders. Below, two food runners, Fernando and Enrique, offer perspective on the matter (interviewed separately):

Author: What are some things you don't like so much [about the job], you know, some things that are kind of challenging?

Fernando: Hmm. I guess the tips. I think that we should maybe get more than 5, 5.5 points, no? We work very hard. I'd like to see less difference between the servers and us. (Interview, February 3, 2017)

Enrique: The only thing that I really ... the only thing is tips. What is it, like 3 percent [of total sales]?

Author: $\quad$ Yeah, sounds right. I think weekend is different; it's 5 percent, but that's with a napkin roller also included. 
Enrique: $\quad$ Yeah. At the other restaurant I work at, I think it's 12 or 15 percent.

Author: What? Wow!

Enrique: $\quad$ I know, so, you know, it's . . . aagggghhh (exasperated). I talked to the manager about it, but he said, that it's just the way we do it. It's like, agghhh! I don't like it, but it's okay. It's just something that you know. It's okay.

(Interview, May 22, 2013)

Fernando and Enrique both make over a hundred dollars in tips from busy shifts at The Neighborhood and Match, respectively. Their grievance is not based on exclusion from tips but rather on how tips are divvied up among tipped and tipped-out workers. The distribution of tips remains a source of tension between them and their white, class-privileged, front-of-the-house workers. As Fernando reasons, "We work very hard, and they should not be making so much more money than we do." Similarly, the way tip money is distributed can also exacerbate the sense of power inequity between worker cohorts. Bussers and food runners must wait for their server colleagues to individually hand them their tips at the end of the shift (at Match) or have a designated front-of-the-house worker divvy up pooled tips and distribute personalized envelopes (at Terroir and The Neighborhood). Servers and bartenders often kept the largest and newest bills for themselves, leaving crumpled small bills for others. Few tipped-out workers went as far as to publicly challenge the extant tip practices of the workplace, either by confronting management or individual servers. Still, their silence on the issue hardly indicates that Latino support workers such as Enrique and Fernando believe the way tip-outs at their respective restaurants are fair.

Other tipped-out workers at Match, Terroir, and The Neighborhood resort to small acts of resistance to strike back, directing their ire against fellow workers, not managers or customers (Mulinari 2016; see also Harris and Ogbonna 2012). Antonio, a Latino food runner at Match in his twenties, told me that he had recently stopped going out of his way to help a certain server because he felt she was tipping him out less than she should be. He figured his diminished food running and bussing support would not be noticeable enough for management to call him out for poor performance, but the server would have to work harder to manage her tables without his help. Antonio recognized that his small act of resistance, as in other weapons of the disempowered (Scott 1985), did not disrupt tip procedures at Match. But for Antonio, his resistance helped balance his perception of the ratio of his labor effort to tips received.

To avoid confronting coworkers about tips, food runners, bussers, and hosts may decide to lodge their complaints with management. Managers then must become intermediaries in attempts to renegotiate the distribution of tips. This strategy, however, seemed to have only limited success, largely because managers at all three restaurants told me they were loath to interfere with "workers' money." The strategy could also backfire should word of the complaint get out. When I first arrived at The Neighborhood, two fellow servers warned me to steer clear of a "bitchy" host named 
Amanda. Amanda, who is a twenty-four-year-old, college-educated, white woman, felt she deserved a larger cut of tips as compensation for all the duties she performed at the restaurant. Word spread of her complaint, and management refused to make any changes. During this time, Amanda's attitude at work changed from upbeat and helpful to cold and slack as more servers avoided interacting with her. She quit two months later.

Fellow servers may also be drawn into tense relations with one another because of tip disputes. Under the pooled tip system at The Neighborhood, tipped workers who do not "pull their weight" can quickly fall out of favor with the rest of the front-of-the-house team. Word can spread fast, and developing a reputation as the chronic underperformer, or worse, freeloader, can be socially damning. Consider the following discussion at The Neighborhood between two servers, Sally and Rudolfo, about their colleague, Rita:

"See?" Sally says in Rita's direction as she exits the restaurant through the back corridor. Sally is clearly frustrated. "Here I am contributing over $\$ 400$ to the pool and Rita is already gone - and she only brought in $\$ 270$. And it's like this practically every time!" An hour later, Sally and Rudolfo tally up the pooled tips on the back counter. They glance at each other, eyeing their total tips in comparison to Rita's. Privately, they decide to split the "extra" cash tips between the two of them instead of putting it toward the tip pot.

"Shhhh," Sally says, looking at me. "It's only fair. Just look at the numbers!" (Field notes, The Neighborhood, August 5, 2016)

Sally and Rudolfo generally agree that pooling tips is a preferable arrangement to handling tips individually - as long as their front-of-the-house coworkers, especially fellow servers, are all able to consistently bring in large tips. Anyone who falls short can compromise the solidarity of the staff. Because of Rita's reputation as a lazy and low-earning server, Sally and Rudolfo flex their own power to put more tips in their pockets and less in Rita's. Neither were they the only servers who took steps to (favorably) correct tip "imbalances" among their colleagues. Such actions also yielded collateral damage, since splitting cash tips instead of placing them in the tip pool also indirectly penalized all other workers and not just the targeted individual.

Similar problems can occur in a pooled tip house when one worker is too skilled at garnering big tips. During Valentine's Day dinner service at Terroir, Bobby, a veteran white server in his late thirties, brought in considerably more tips than the five other servers working that shift and nearly three times more than the lowest-earning server. Bobby could barely contain his disgust at the prospect of splitting tips equally. He complained to one of the managers who, perhaps out of fear of losing his best server, promptly announced a one-day exception to the existing tip pool policy to allow for an alternate distribution of tips that day. Dissatisfaction among the staff about this decision lingered for weeks afterward.

In some ways, the individualized tip system at Match hedges against just such tensions between tipped workers. However, it can challenge worker relations in different ways. At Match, in spite of the restaurant's protocol of assigned table sections, 
servers jockey with each other for the right to wait on certain groups of diners they think will tip them well. Problems arise when workers overstep unwritten rules. For instance, after two months of working at Match, I became aware of an informal etiquette for covering servers' tables during lunch breaks. Formally, any new group of diners seated in the absent server's section is handled by the server covering that section. Informally, if any new group of four or more arrives in that section, the covering server is expected to notify the absent server to give the option of returning to work to avoid missing out on the tip. Violating this informal norm by following formal rules can quickly lead one to be blacklisted by fellow servers. Antonio, a Mexican immigrant in his mid-fifties, was notorious among his coworkers for not respecting the informal rules. Annabelle, a white server in her twenties, explained to me:

If I let Antonio cover me during break? Hell, I'd come off break and find my section completely full. Then I'd be waiting an hour just to get a table free again. That's why no one asks him to cover when they go on break. (Field notes, Match, July 14, 2012)

Antonio's approach toward waiting tables at Match isolated him from other servers at the restaurant. It impeded his social ties with colleagues with whom he shared little in common with based on race and class. This did not appear to bother Antonio much, who later told me he viewed waiting tables purely as a hustle with no place for socializing. Others, such as Annabelle, are far less willing to let their rapport with their tipped coworkers - and social peers - fall by the wayside.

At all three restaurants, tensions among tipped workers tend to decrease when, as a server named Nathan put it, "The money is good anyway, baby!" A busy night tends to lift all boats among tipped workers whereas a slow night can bring out simmering feuds over tips. In general, tipped, tipped-out, and untipped workers alike would rather not cause interpersonal conflict over tips in a workplace where they must interact so closely with their coworkers. That does not mean that these tensions do not exist. When tip disparities become too glaring or too unforgivable, they swell into overt conflict.

\section{FOSTERING TENUOUS ALLIANCES}

Tipped workers at Match, Terroir, and The Neighborhood understand that the ability to optimize their tips is about having the right set of opportunities in the workplace. Making "good money" in tips is not just about getting lucky with a few generous diners, it involves strategizing one's approach toward other social and material aspects of the workplace (see Kim, Nemeschansky, and Brandt 2017; Paules 1991; Sallaz 2009). As a result, many of these workers view their interactions with managers and back-of-the-house workers as potential sources of on-the-job social capital. This can result in tenuous alliances forged with colleagues who will not receive a formal cut of tips.

Front-of-the-house workers at each restaurant negotiate with scheduling managers to secure more favorable shifts. Because the number of workers present on the 
floor directly affects tips, daily managerial decisions regarding scheduling and "cutting" (releasing workers early) can dramatically swing the tip pool (see Lambert, Haley-Lock, and Henly 2012). This makes some traditionally undesirable shifts, such as slow weekdays, unexpectedly lucrative. At Terroir, several of my coworkers expressed more enthusiasm at being scheduled to work the Wednesday night dinner shift, when only three servers were scheduled, than Friday nights, when six servers were scheduled. It also colors workers' relationships with different managers. At The Neighborhood, servers liked to evaluate a new manager's performance based on their propensity to "short staff" (schedule less workers) and cut labor quickly. Mary Ann, a white server in her thirties, considers a manager incompetent if he or she consistently overstaffs and refuses to send workers home as business dies down. Servers will negotiate staffing with new management, as my field notes on a slow Tuesday night at The Neighborhood demonstrate:

It is 5:30 p.m., the start of dinner service.

Rachael, Morgan, and Julie [servers] approach Ernest [floor manager] to plead their case for cutting staff tonight. "C'mon Ernest, it's a Tuesday night. Why are we all here right now?" Morgan says.

Ernest shrugs apologetically. "Boss's orders, not my call," he says. "If it is still slow by 8:00 p.m., I'll let someone go, but we have to open with four of you."

Rachael, Morgan, and Julie walk away wordlessly, dejected. "I'd rather get my ass kicked and make some good money than be standing around all night," Julie says under her breath.

(Field notes, The Neighborhood, February 3, 2017)

In the above scenario, Ernest, then only two months into his tenure as a floor manager at The Neighborhood, was uncomfortable risking being short-staffed should a large party of diners arrive without reservations. Rachael, Morgan, and Julie - each of whom had worked at The Neighborhood for several years - had little patience for Ernest's conservative approach to cutting labor.

By contrast, these same servers praise Peter's approach to managing the front-of-the-house staff. Peter, who is twenty-nine years old and white, takes a proactive approach to making cuts. In Morgan's words, "Peter is on our side." The following is from a group text message between Peter and four servers (including myself):

Peter: We have twenty-nine on the books tonight. Who wants to take the cut?

Rachael: $\quad$ I need the money, sorry.

Julie: $\quad$ Me! Pleeeeaaase!!

Peter: $\quad$ You got it Julie. Anyone else?

Author: Wait, you are cool running with just two [servers]?

Peter: $\quad$ Yeah. It's going to be slow tonight and if we get busy, I'll just have to jump in there and show you all how it is done!

(Field notes, The Neighborhood, January 15, 2017) 
Shortly after his arrival at the restaurant in the fall of 2016, Peter began garnering the admiration of servers for his bold managerial decisions regarding "running short," or risking being short-staffed to maximize server tips. Peter's willingness to help wait tables if needed - without taking any tips for doing so - enshrined him as the manager who is "on our side." Servers would look over their weekly schedules hoping that he - and not Ernest - was the manager on duty when they were working. Peter was also invited to a number of functions servers hosted outside of work, such as movie nights, holiday parties, and bar-hopping.

Tipped workers also approach their relations with the schedule managers very strategically. At all three restaurants, the scheduling manager draws up not only weekly schedules for the front of the house but also daily floor sections that denote the area of the restaurant each server will operate in. At Match, where tips are not pooled, some floor sections are widely considered more lucrative than others, just as some shifts are. This amounts to a mini-hierarchy of sections, with the top tip-earning shifts highly coveted. Lilly, a server at Match, told me she views maintaining strong ties with the scheduling manager as among her top priorities on the job. Similarly, a new server hired at The Neighborhood in the winter of 2016 arrived early and stayed late every day until he had cultivated cache with management to work the lucrative Friday and Saturday night shifts. For tipped workers at each restaurant, accessing the best tip-making opportunities each week is half the battle.

Front-of-the-house workers also approach their relations with fellow workers with considerable strategic planning. Like merchants at a trading port, fellow servers give away, trade, and offer to cover shifts. At stake are unequal opportunities to make tips. At Terroir, a Friday dinner shift might yield 30\% more in tips than a Wednesday dinner shift, while any dinner shift will nearly yield double the tips of a lunch shift. Thus, trading away a coveted Saturday night shift to another worker can build serious goodwill with that individual. Such a trade can also be a loaded "gift," a gesture that anticipates a reciprocal action in the future. For instance, at Terroir, when Nathan, a white server in his early twenties, found he was scheduled for the notoriously slow Monday lunch shift, he immediately appealed to me: "C'mon Eli, don't you remember when I let you have my Saturday night last week? Work Monday for me, buddy. You owe me" (Field notes, Terroir, November 17, 2015).

Some servers and bartenders also make efforts to form alliances with untipped workers in the kitchen; the quicker the food flows to diners, the better the front-of-the-house workers' chances for good tips. Tipped workers thus attempt to curry favor with the majority Latino and Spanish-speaking kitchen staff through small gestures, such as replenishing sodas midshift, buying occasional post-shift beers, or less commonly, sharing a small portion of tips under the table. These gestures function as gift giving, in the sense that they are selectively extended and retracted and come with the expectation of a return (Mauss 1925). They also differ under Match's system of individualized tips versus the pooled tip houses of Terroir and The Neighborhood. At Match, Susie, a white server in her mid-twenties, takes time to ensure that the large soda containers of the two lead cooks, Xeno and 
Rodrigo, are never empty during her shifts. Though Susie struggles to communicate in Spanish with them, she nonetheless points to the container on the counter and utters, "Want more?" A twenty-eight-year-old server named Leroy was fond of offering cooks a five- or ten-dollar bill on days he expected to have a full section of diners, to ensure that his special requests for food were executed without hassle. Consequently, his requests would sometimes leap-frog other servers' requests. As Leroy explained it, "I don't do it all the time because that would start adding up. But I want to make sure those guys are on my side when I need them."

At Terroir and The Neighborhood, front-of-the-house workers adopt a more collective approach to currying favor from non-tipped workers. For instance, after a busy weekend dinner service at The Neighborhood, servers take turns purchasing "kitchen beers": a six-pack for cooks to sip on while cleaning. Others would informally gather together "the juice" - a few extra dollars from the daily tip pool that could not be divided evenly - and put it toward a monthly pot intended for kitchen workers. For example, after a Friday night shift in the winter of 2016, I watched Rachael count out fifteen crumpled dollar bills from the previous month's kitchen pot. She placed the money in a white envelope and labeled it "kitchen," and handed it over to the manager on duty. This mirrored what she had done earlier in the night when distributing much larger sums of cash tips to the front-of-the-house staff: $\$ 210$ for each server, $\$ 105$ for each busser, and $\$ 35$ for the host. As Rachael reasoned, "I know it isn't much, but they'll appreciate it, right?" Two months later, the practice of giving the juice from the tip pool to the kitchen stopped abruptly at The Neighborhood. Somehow, the previous month's kitchen tips had gone missing (something I always reasoned was a possibility given how poorly the kitchen tip envelope was secured). Without informing or consulting any kitchen worker of their decision, Rachael and her server colleagues never bothered to reinstitute the practice.

For Rachael, Susie, and Leroy, extending gift-like gestures of goodwill toward kitchen workers, management, and fellow tipped workers help them optimize their chances to make more tips. It is something that they must renegotiate every time they clock in for a shift, and can easily degrade. It is also discretionary, a reminder of power inequities that exist between different workers at the restaurant. Nonetheless, these informal strategies, from refilling sodas to setting aside kitchen tips, exemplify a larger web of social ties present within the workplace and complicated by tips.

\section{DIFFERENTIATING CASH TIPS AND PAYCHECK WAGES}

How servers and bartenders in this study handle their tips can also deepen tensions between tipped and untipped workers in the same workplace. This tension extends beyond the economic disparity that tipping reinforces; it incorporates how tips are used and what they represent to the race- and class-privileged workers who make them. Cash tips, which are typically distributed at the end of the shift, are what tipped workers frequently use to fuel consumption-driven lifestyles, such as socializing after their shifts at nearby bars and restaurants. These actions - and the conspicuous use 
of cash tips to furnish them - estrange the everyday work subcultures of tipped workers and untipped coworkers at the restaurant. They reinforce class differences between these subgroups that are also inflected with ethno-racial distinctions. ${ }^{6}$

The medium with which tipped and untipped workers receive the bulk of their earnings matters. Few of the class-privileged, white servers and bartenders at Match treat a twenty-dollar cash tip left folded on the table the same as twenty dollars inked on their bimonthly paychecks. Workers "earmark" the two differently (Zelizer 1993), categorizing and spending them in distinct ways. Paycheck earnings, as Charlie, a white, college-educated server, put it, are funds he designates exclusively for core expenses, like rent, taxes, and bills (though he admits his paycheck alone cannot cover all these). By contrast, tips he sees as "extra," which he occasionally uses to buy rounds of drinks after work or to attend local music concerts.

Other tipped workers describe the potentially seductive, intoxicating quality of being flush with cash and full of energy after a busy dinner shift in a highly social atmosphere. At all three restaurants in this study, a revolving group of servers and bartenders would routinely head out to nearby bars for drinks and merriment after their shifts, often staying until the 2:00 a.m. closing time. Kathy, a twenty-three-year-old white server at The Neighborhood, adds sheepishly that when she goes out after work, she can be careless about how much she ends up spending on drinks and entertainment. "I'll ask for one beer and leave a twenty-dollar bill," she explains, only half-jokingly. "Sometimes, I really don't remember."

Others use their cash tips to assume the role of the generous tipper. Below, two white servers at The Neighborhood, Rachael and Julie, recount postshift revelries:

$\begin{array}{ll}\text { Rachael: } & \text { "Sometimes I'll come back from a night out, and I'll have nothing } \\ & \text { left. Like, where did it all go? And did I just hand all my tips over } \\ \text { as a tip for the bartender?" } & \text { "I've learned I have to control myself. I go to the bank as soon as } \\ \text { I get my tips now, because I know what'll happen if I bring that } \\ \text { shit out." } \\ \text { (Field notes, The Neighborhood, July 9, 2016) }\end{array}$

For Rachael and Julie, cash tips are woven into their broader lifestyles that involve nightlife and consumption of entertainment. While these two servers exhibit competing personal philosophies regarding tip spending (discussed below), having received cash tips, both are more likely to fraternize with fellow tipped workers at other bars and restaurants than with their own untipped and tipped-out Latino colleagues. Cash tips function as entertainment currency circulated almost exclusively among class-privileged white workers.

Others note that the casual way they see affluent diners treat tipping influences how workers themselves view the act:

Tonight I waited on a group of two men and two women who appear to be having a celebratory meal comprised of steak and expensive red wine. At the end of their meal, I thank them for coming in, right then deciding that the service I have given 
them was probably satisfactory enough to expect to see an 18-20 percent tip on their total bill of $\$ 290$ (roughly a $\$ 55$ tip). Instead, they leave $\$ 200$ - almost 100 percent of their bill! I am so shocked that I immediately show the signed receipt to Rachael and Morgan. Neither seems particularly surprised.

"Oh yeah, that guy always does that when he comes in, leaves us a huge tip. He's so nice," says Morgan. After the shift, we, along with Rafael (food runner) and Andrew (cook), go out to our usual Irish pub.

"Drinks on that guy!" says Rachael, gesturing back in the direction of the restaurant. She orders a round of beer for everyone.

(Field notes, The Neighborhood, September 28, 2016)

The $\$ 200$ tip that contributed to our tip pool that night was an unexpected windfall. Most of it was spent with similar swiftness and whim at the bar, spurred on by Rachael and Morgan. For Rachael, receiving an abnormally large tip feels different from hard-earned income, and her subsequent actions occasionally reflect this. That night, within thirty minutes, the tip money was gone. No one suggested we squirrel it away for a rainy day or share it with our colleagues in the kitchen.

The gratification of spending tips on entertainment can also give way to overindulgence, something tipped workers are likely to note is the dark side of a work culture built around cash tips, booze, and partying. Some have developed personalized strategies to help them curtail the temptation to spend cash tips too loosely. Brady, a white bartender at Terroir who has been working in restaurants since he was sixteen, leaves his tips in Terroir's locked safe and takes them home weekly instead of daily. This way, Brady figures, he reduces the likelihood of spending his tips as soon as he gets them. As he puts it, "if it is just $\$ 100, \$ 150$ dollars? I'm the kind of guy who will want to go out, treat myself and my friends right for an evening, you know?" (Interview, March 7, 2016).

Longtime servers and bartenders are more likely to exhibit a measured approach to cash tips than industry newcomers. By deliberately treating cash tips as they would numbers on a paycheck, these workers more closely model the financial behavior of their untipped restaurant colleagues. When I met Bobby, a server at Terroir in his late thirties, he had recently reduced his drinking - especially post-shift drinking. It was a decision he says he made in conjunction with his first committed relationship in years. "I had to get smart about things," he explained. "When I was younger, I was the life of the party. Nowadays, I'll still smoke and stuff on occasion, but I had to cut the rest of that shit out, the hard drugs and all" (Interview, November 11, 2015). Similarly, a forty-year-old white server named Julie says she has learned to check her spending behavior and drinking after work; immediately after her shifts, she marches her cash tips to a nearby bank to deposit them in her checking account, save for a lone twenty-dollar bill for the bar.

Still, the unique relationship that front-of-the-house workers have with tips also shapes their long-term perspectives on the work they do in ways that deviate from their back-of-the-house Latino colleagues. Several white, class-privileged servers and 
bartenders expressed to me that working tipped jobs in restaurants comes to feel more like a trap than a career, with tips being the central lure. For example, Sarah, a college-educated, white server, left Match for what she thought was a more serious and respectable white-collar career at a nearby recruitment agency. Six months later, however, she was back to waiting tables. As Sarah explained, "I really thought I'd like [working at the recruitment firm]. But I couldn't stand sitting all day at that office, not talking to anyone. Plus, I made way less money too." Waiting tables and making tips at Match suited her better, but at a cost: "You keep telling yourself that you are getting out of waiting tables, out of restaurants, out of making tips. Then the next time you look up, it's been years, and you are still doing it. And you're like, where did that time go? And where'd all my money go?" (Field notes, May 14, 2013).

\section{DISCUSSION AND CONCLUSION}

This study shows that the implications of tipping extend well beyond the service counter where gratuities are originally transacted. Tips, and how they are handled, affect relations between different groups of service workers with structurally unequal access to this form of earnings. While the majority of scholarship on tipping focuses primarily on customer-worker dynamics - the "front stage" of tipping - I develop a broader scope of analysis on tip work: the assemblage of social relations and labor experiences in an interactive service setting that are shaped by the presence of tips. Studying the "work" of tipping demonstrates how gratuities shape intralabor dynamics "back stage" in the workplace, sharpening differences between types of service workers who may be tipped, tipped-out, and untipped. The uneven distribution of tips among these individuals brings about nuanced strategies that each use to approach their jobs, their earnings, and each other. Seen from an interactionist perspective, tips mediate how different workers interpret and constitute their relations with one another in the workplace.

Drawing on an illustrative case of restaurant workers in three upscale Los Angeles restaurants, this study shows that tips exacerbate organizational divides between coworkers who otherwise take part in conjoined aspects of the food service process. The unequal distribution of tips between front-of-the-house and back-of-the-house workers also deepens existing social cleavages of race, class, and gender in the workplace. While tipping can lead to strategic alliances between these subgroups of service workers (see Lewis 2006), it more often adds to chronic workplace tensions and fraught alliances (characterized by tit-for-tat gift giving). Because of tips, racialized, classed, and gendered service jobs in restaurants like the ones in this study come to represent substantially unequal opportunities. Moreover, the differential access to tips among different workers affects the ways in which socially distinct employee subgroups approach their jobs and their earnings. Many of the white, class-privileged servers and bartenders at Match, Terroir, and The Neighborhood use cash tips for casual leisure spending. In doing so, they participate in a tipped work culture that 
is not shared with their untipped back of the house colleagues, many of whom are working-class, immigrant Latinos.

This research also reveals how tip work shapes vertical labor relations between workers and management. As Sallaz (2009) has noted, efforts to maximize tips lead some tipped workers to engage in "entrepreneurial games" with customers; these games simultaneously make the former less likely to locate their labor grievances with management and instead blame bad tippers. My research corroborates these findings while also extending them to show how tipped workers may also become willing accomplices in management-friendly labor schemes such as short-staffing and “cutting" (Lambert, Haley-Lock, and Henly 2012), often at the expense of fellow workers. Put differently, the white, class-privileged tipped workers in this study uphold many of workplace policies (e.g., distribution of tips) that act to subordinate their tipped-out and untipped, working-class, Latino colleagues. The persistence of tipping, at least in the United States, may be because of how conveniently the system upholds the capitalist interests of dominant groups comprised of both managers and privileged workers.

As this study reveals, the social dynamics of tip work are closely linked to the workplace conditions, norms, and policies where they are found. Organizationally, this includes whether tips are pooled or handled on an individual basis, how gratuities are distributed among workers (e.g., the proportion given to support workers), and whether tips are provided to workers in cash or processed with one's paycheck. In this sense, structural opportunities for tip-making vary not just across institutional environments (see Sallaz 2009) but within specific workplaces in which shop policies and relational practices shape access to gratuities. The social organization of work by race, class, and gender in many urban, tipped service settings also plays an important role in understanding the implications of tip work. While I do not suggest that the unequal distribution of tips brings about the social segmentation of restaurant work, the two phenomena exist together and with conjoined effects: the unequal earning opportunities that tips engender sharpen distinctions between those in the front-of-the-house and back-of-the-house.

The nature of tip work described in this study is also likely to be similar to that found in many other urban interactive service and hospitality settings in the United States. Many of these workplaces maintain a similar cast of tipped, tipped-out, and untipped workers that are patterned by race, class, and gender (see Sallaz 2009; Sherman 2007; Subramanian and Suquet 2017). That said, the labor dynamics within other tipped workplaces will be nuanced by local shopfloor policies (e.g., abandoning tips for a fixed service charge), the social organization of work (e.g., a foreign-born, non-white customer service team), and state-based labor laws (e.g., presence or absence of a tipped minimum wage). For example, extending the findings of this study, it would be interesting for future research to tease out the specific effects of tip work through a comparative restaurant case that does not feature tipping.

This research makes an important contribution to the growing body of scholarship on tipped employment and interactive service work by demonstrating how 
the institution of tipping contributes to workplace inequalities beyond the service counter. Tips cannot simply be understood as a derivative of customer behavior but a social process shaping its own outcomes. Analyzing tip work at the level of the shop floor also draws needed attention to intralabor divisions found within many settings of interactive service labor today (Subramanian and Suquet 2017; Wilson 2017). Future analyses of tip work should continue interrogating contemporary tipped workplaces using ethnographic methods adept at capturing how particular workers negotiate the social and structural organization of their labor settings. Likewise, subsequent research could also follow tipped workers beyond brick and mortar workplaces and into the realm of on-call, personalized services. Many New Economy gigs (e.g., DoorDash or Uber) involve some degree of tipping to complete the transaction. These jobs are also mobile, flexible, and performed in isolation from immediate coworkers (though still linked to a larger arc of labor getting the product to customer). As tipped employment extends beyond familiar locales, scholars need to approach the issues surrounding it with fresh tools and renewed focus on understanding the myriad sociological implications of tipping.

\section{ACKNOWLEDGMENTS}

The author would like to thank Ödül Bozkurt, Julie Monroe, and several anonymous reviewers for their valuable feedback on this article. He would also like to acknowledge the Institute for Research on Labor and Employment at UCLA for funding support.

\section{NOTES}

1. According to the Fair Labor Standards Act, workers who are not considered part of the line of direct customer service are ineligible to receive tips.

2. This was true at all three restaurants in this study, and is in line with the tip-out rates described by Gomberg-Muñoz (2011).

3. My sense is that these earning figures for tipped restaurant workers represent the higher range for the industry as a whole. Restaurant workers in non-urban contexts and less trafficked establishments will earn less.

4. New York Times food critic Pete Wells (2013) goes so far as to claim that tips induce "a perpetual state of class warfare" between restaurant employees.

5. It was expedient for me to seek a position as a server because my previous restaurant experience is all in the dining room, as a server, bartender, floor supervisor, and food runner. My physical characteristics also matched many of the socio-culturally-informed requirements for this line of work: I was in my mid-twenties and college-educated, had an athletic physique, and could pass for white.

6. I elaborate on this point elsewhere (see Wilson 2017).

\section{REFERENCES}

Adler, Patricia and Peter Adler. 2004. Paradise Laborers: Hotel Work in the Global Economy. Ithaca: Cornell University Press. 
Azar, Ofer. 2004. "The History of Tipping - From the Sixteenth-Century England to United States in the 1910s." The Journal of Socio-Economics 33(6):745-764.

Azar, Ofer. 2007. "The Social Norm of Tipping: A Review." Journal of Applied Social Psychology 37(2):380-402.

Azar, Ofer. 2011. "Business Strategy and the Social Norm of Tipping." Journal of Economic Psychology 32:515-525.

Bearman, Peter. 2009. Doormen. Chicago: University of Chicago Press.

Brewster, Zachary and Christine Mallinson. 2009. "Racial Differences in Restaurant Tipping: A Labour Process Perspective.” The Service Industries Journal 29(8):1053-1075.

Brewster, Zachary and Jeremiah Wills. 2013. "The Institution of Tipping as a Source of Employee Agency: The Case of Restaurant Servers." Sociological Focus 46(3):193-210.

Cantazarite, Lisa. 2000. "Brown-Collar Jobs: Occupational Segregation and Earnings of Recent-Immigrant Latinos." Sociological Perspectives 43(1):45-75.

Cobble, Dorothy Sue. 1991. Dishing It Out: Waitresses and Their Unions in the Twentieth Century. Chicago: University of Illinois Press.

Conlin, Michael, Michael Lynn, and Ted O'Donoghue. 2003. "The Norm of Restaurant Tipping." Journal of Economic Behavior \& Organization 52:297-321.

Corman, Michael. 2017. "Driving to Work: The Front Seat Work of Paramedics to and from the Scene." Symbolic Interaction 41(3):291-310.

Crusco, April and Christopher Wetzel. 1984. "The Midas Touch: The Effects of Interpersonal Touch on Restaurant Tipping." Personality and Social Psychology Bulletin 10:512-517.

Davis, Fred. 1959. "The Taxi Driver and His Fare: Facets of a Fleeting Relationship." American Journal of Sociology 65(2):158-165.

Ehrenreich, Barbara. 2001. Nickel and Dimed: On (Not) Getting by in America. New York: Metropolitan Books.

Emerson, Robert M., Rachel I. Fretz, and Linda L. Shaw. 2011. Writing Ethnographic Fieldnotes. 2nd ed. Chicago: University of Chicago Press.

Erickson, Karla A. 2009. The Hungry Cowboy: Service and Community in a Neighborhood Restaurant. Jackson, MS: University Press of Mississippi.

Ferro, Shane. 2015. "There's a Shortage of Cooks in America. Here's the Simple Solution.” The Huffington Post, October 21. Retrieved December 30, 2018 (http://www.huffingtonpost.com/ entry/cook-shortage-restaurant-pay_us_5627b438e4b08589ef4a031d).

Fine, Gary A. 2009. Kitchens. Berkeley: University of California Press.

Foshay, Karen. 2016. "Wage Theft: Millions Stolen, Little Recovered within the Restaurant Industry." KCRW, August 1. Retrieved December 30, 2018 (http://curious.kcrw.com/2016/08/ wage-theft).

Gatta, Mary. 2002. Juggling Food and Feelings: Emotional Balance in the Workplace. Lanham, MD: Lexington Books.

Gomberg-Muñoz, Ruth. 2011. Labor and Legality: An Ethnography of a Mexican Immigrant Network. New York: Oxford University Press.

Haley-Lock, Anna and Stephanie Ewert. 2011. "Waiting for the Minimum: US State Wages Laws, Firm Strategy, and Chain Restaurant Job Quality." Journal of Industrial Research 51(1):31-48.

Harris, Lloyd and Emmanuel Ogbonna. 2012. "Motives for Service Sabotage: An Empirical Study of Front-Line Workers." The Service Industries Journal 32(13):2027-2046.

Jayaraman, Saru. 2014. Behind the Kitchen Door. Ithaca: Cornell University Press.

Jayaraman, Saru. 2018. Forked: A New Standard for American Dining. New York: Oxford University Press.

Katz, Jack. 1997. “Ethnography's Warrants.” Sociological Methods \& Research 25(4):391-423. 
Kim, Peter B., Ben Nemeschansky, and Lothar Brandt. 2017. "An Exploratory Study of Determinants for Restaurant Servers' Actual Tip Earnings: Individual Characteristics and Work Conditions." Journal of Food Service Business Research 20(1):15-33.

Lambert, Susan, Anna Haley-Lock, and Julia Henly. 2012. "Schedule Flexibility in Hourly Jobs: Unanticipated Consequences and Promising Directions." Community, Work \& Family 15(3):293-315.

Lewis, Jacqueline. 2006. “'I'll Scratch Your Back if You'll Scratch Mine': The Role of Reciprocity, Power and Autonomy in the Strip Club." Canadian Review of Sociology and Anthropology 43(3):297-311.

Lloyd, Richard. 2010. Neo-Bohemia: Art and Commerce in the Postindustrial City. 2nd ed. New York: Routledge.

Lopez, Steven. 2010. "Workers, Managers, and Customers: Triangles of Power in Work Communities." Work and Occupations 37(3):251-271.

Lynn, Michael W. 2006. "Tipping in Restaurants and around the Globe: An Interdisciplinary Review." Pp. 626-643 in Handbook of Contemporary Behavioral Economics: Foundations and Developments, edited by M. Altman. New York: Sharpe.

Lynn, Michael and Bibb Latane. 1984. "The Psychology of Restaurant Tipping." Journal of Applied Social Psychology 14(6):549-561.

Lynn, Michael and Michael McCall. 2000. "Gratitude and Gratuity: A Meta-Analysis of Research on the Service-Tipping Relationship." The Journal of Socio-Economics 29:203-214.

Mars, Gerald and Michael Nicod. 1984. The World of Waiters. London: George Allen and Unwin.

Mauss, Marcel. 1925. The Gift. New York: Norton.

Mulinari, Paula. 2016. "Weapons of the Poor: Tipping and Resistance in Precarious Times." Economic and Industrial Democracy 1-18. https://doi.org/10.1177/0143831X16653188.

Ocejo, R. 2014. Upscaling Downtown. Princeton: Princeton University Press.

Paules, Greta F. 1991. Dishing It Out: Power and Resistance among Waitresses in a New Jersey Restaurant. Philadelphia: Temple University Press.

ROCU (Restaurant Opportunities Centers United). 2014. The Great Service Divide: Occupational Segregation and Inequality in the US Restaurant Industry. Restaurant Opportunities Centers United. Retrieved December 30, 2018 (http://rocunited.org/publications/the-great-servicedivide-national/).

Ronai, Carol and Carolyn Ellis. 1989. "Turn-Ons for Money: Interactional Strategies of the Table Dancer." Journal of Contemporary Ethnography 18:271-298.

Sallaz, Jeffrey. 2009. The Labor of Luck: Casino Capitalism in the United States and South Africa. Berkeley: University of California Press.

Santino, Jack. 1989. Miles of Smiles, Years of Struggle: Stories of Black Pullman Porters. Urbana: University of Illinois Press.

Schein, John E. and Barbara R. Wohlfahrt. 1984. The Art of Tipping: Customs \& Controversies. Wausau, WI: Tippers International.

Scott, James. 1985. Weapons of the Weak: Everyday Forms of Peasant Resistance. New Haven: Yale University Press.

Segrave, Kerry. 1998. Tipping: An American Social History of Gratuities. Jefferson, NC: McFarland.

Sherman, Rachel. 2007. Class Acts: Service and Inequality in Luxury Hotels. Berkeley: University of California Press.

Spradley, James P and Brenda Mann. 1975. The Cocktail Waitress: Woman's Work in a Man's World. New York: Wiley.

Strauss, Anselm. 1985. "Work and the Division of Labor." The Sociological Quarterly 26(1):1-19.

Subramanian, Dilip and Jean-Baptiste Suquet. 2017. "Unpacking the Service Triangle: Arranging Power Relations between Frontline Occupations." Work and Occupations 45(1):38-81.

Thompson, Alex. 2015. "Wrangling Tips: Entrepreneurial Manipulation in Fast-Food Delivery." Journal of Contemporary Ethnography 44(6):737-765. 
US Bureau of Labor Statistics. 2017. "Occupational Outlook Handbook.” Updated April 13, 2018. Retrieved December 30, 2018 (https://www.bls.gov/ooh/food-preparation-and-serving/cooks .htm).

Waldinger, Roger and Michael Lichter. 2003. How the Other Half Works. Berkeley: University of California Press.

Wells, Pete. 2013. "Leaving a Tip: A Custom in Need of Changing?" New York Times, September 3. Retrieved December 30, 2018 (https://www.nytimes.com/2013/09/04/dining/leaving-a-tipa-custom-in-need-of-changing.html? partner=rss\&emc=rss\&pagewanted=all).

Williams, Christine and Catherine Connell. 2010. "'Looking Good and Sounding Right': Aesthetic Labor and Social Inequality in the Retail Industry." Work and Occupations 37(3):349-377.

Wilson, Eli R. 2016. "Matching Up: Producing Proximal Service in a Los Angeles Restaurant." Research in the Sociology of Work 29:99-124.

Wilson, Eli R. 2017. "Serving Across the Divide: Race, Class, and the Production of Restaurant Service." PhD dissertation, Department of Sociology, University of California, Los Angeles. Zelizer, Viviana. 1993. The Social Meaning of Money. New York: Russell Sage Foundation.

\section{ABOUT THE CONTRIBUTOR(S)}

Eli R. Wilson is an Assistant Professor of Sociology at the University of New Mexico. His research employs mixed qualitative methods to examine how social inequality is both reproduced and challenged in urban labor markets. His current project examines racialized and gendered career pathways in the craft beer industry. Dr. Wilson's published works can also be found in Ethnic and Racial Studies, Research in the Sociology of Work, and The Russell Sage Foundation Journal of the Social Sciences. 